\title{
Nitrous oxide distribution and its origin in the central and eastern South Pacific Subtropical Gyre
}

\author{
J. Charpentier ${ }^{1,2}$, L. Farias ${ }^{2}$, N. Yoshida ${ }^{3,4}$, N. Boontanon ${ }^{4,5}$, and P. Raimbault ${ }^{6}$ \\ ${ }^{1}$ Programa de Postgrado, Departamento de Oceanografía, Facultad de Ciencias Naturales y Oceanográficas, Universidad de \\ Concepción, Chile \\ ${ }^{2}$ Departamento de Oceanografía \& Centro Oceanográfico del Pacífico Sur (COPAS), Universidad de Concepción, \\ Concepción, Chile \\ ${ }^{3}$ Frontier Collaborative Research Center, Tokyo Institute of Technology, Midori-ku, Yokohama, Japan \\ ${ }^{4}$ SORST project, JST, Kawaguchi, Saitama, Japan \\ ${ }^{5}$ Faculty of Environment and Resource Studies, Mahidol University 999 Phuttamonthon 4 Road, Phuttamonthon, Salaya, \\ Nakhon Pathom 73170, Thailand \\ ${ }^{6}$ Laboratoire d'Océanographie et de Biogéochimie (CNRS UMR 6535), Centre d'Océanologie de Marseille, Campus de \\ Luminy, Marseille Cedex, France
}

Received: 10 May 2007 - Published in Biogeosciences Discuss.: 25 May 2007

Revised: 22 August 2007 - Accepted: 12 September 2007 - Published: 13 September 2007

\begin{abstract}
The mechanisms of microbial nitrous oxide $\left(\mathrm{N}_{2} \mathrm{O}\right)$ production in the ocean have been the subject of many discussions in recent years. New isotopomeric tools can further refine our knowledge of $\mathrm{N}_{2} \mathrm{O}$ sources in natural environments. This study compares hydrographic, $\mathrm{N}_{2} \mathrm{O}$ concentration, and $\mathrm{N}_{2} \mathrm{O}$ isotopic and isotopomeric data from three stations along a coast-perpendicular transect in the South Pacific Ocean, extending from the center (Sts. GYR and EGY) of the subtropical oligotrophic gyre $\left(\sim 26^{\circ} \mathrm{S} ; 114^{\circ} \mathrm{W}\right)$ to the upwelling zone (St. UPX) off the central Chilean coast $\left(\sim 34^{\circ} \mathrm{S}\right)$. Although $\mathrm{AOU} / \mathrm{N}_{2} \mathrm{O}$ and $\mathrm{NO}_{3}^{-}$trends support the idea that most of the $\mathrm{N}_{2} \mathrm{O}$ (mainly from intermediate water (200-600 m)) comes from nitrification, $\mathrm{N}_{2} \mathrm{O}$ isotopomeric composition (intramolecular distribution of ${ }^{15} \mathrm{~N}$ isotopes) expressed as SP (site preference of ${ }^{15} \mathrm{~N}$ ) shows low values (10 to $12 \%$ ) that could be attributed to the production through of microbial nitrifier denitrification (reduction of nitrite to $\mathrm{N}_{2} \mathrm{O}$ mediated by ammonium oxidizers). The coincidence of this SP signal with high - stability layer, where sinking organic particles can accumulate, suggests that $\mathrm{N}_{2} \mathrm{O}$ could be produced by nitrifier denitrification inside particles. It is postulated that deceleration of particles in the pycnocline can modify the advection - diffusion balance inside particles, allowing the accumulation of nitrite and $\mathrm{O}_{2}$ depletion suitable for nitrifier denitrication. As lateral advection seems to be relatively insignificant in the gyre, in situ nitrifier denitrification could account for $40-50 \%$ of the $\mathrm{N}_{2} \mathrm{O}$ produced in this
\end{abstract}

Correspondence to: J. Charpentier

(jcharpentier@profc.udec.cl) layer. In contrast, coastal upwelling system is characterized by $\mathrm{O}_{2}$ deficient condition and some $\mathrm{N}$ deficit in a eutrophic system. Here, $\mathrm{N}_{2} \mathrm{O}$ accumulates up to $480 \%$ saturation, and isotopic and isotopomer signals show highly complex $\mathrm{N}_{2} \mathrm{O}$ production processes, which presumably reflect both the effect of nitrification and denitrification at low $\mathrm{O}_{2}$ levels on $\mathrm{N}_{2} \mathrm{O}$ production, but net $\mathrm{N}_{2} \mathrm{O}$ consumption by denitrification was not observed.

\section{Introduction}

$\mathrm{N}_{2} \mathrm{O}$ exists in the atmosphere at trace levels. However, this "greenhouse gas" is of great environmental importance. It is 170 to 300 times more efficient (per molecule) than $\mathrm{CO}_{2}$ (Manne and Richels 2001) in trapping infrared radiation and accounts for 5-6\% of the greenhouse effect (Law and Ling 2001). The oceans are a net source of $\mathrm{N}_{2} \mathrm{O}$ for the atmosphere, with an estimated average annual emission of $6 \mathrm{Tg} \mathrm{N}$ year $^{-1}$, corresponding to $20 \%$ of the global emissions (Nevison et al., 1995).

The relative importance of the biological processes producing $\mathrm{N}_{2} \mathrm{O}$ remains unclear. Nitrification is a chemotrophic process by which $\mathrm{NH}_{4}^{+}$and $\mathrm{NO}_{2}^{-}$are aerobically oxidized to fix inorganic carbon. These reactions are carried out in two stages by different groups of microorganisms (Ward 2000). The first stage is ammonium oxidation to nitrite, carried out by microorganisms called ammonium-oxidizers. In this reaction, hydroxylamine acts as an intermediate and has been proposed as a precursor of $\mathrm{N}_{2} \mathrm{O}$, although the biochemical

Published by Copernicus Publications on behalf of the European Geosciences Union. 
NITRIFICATION

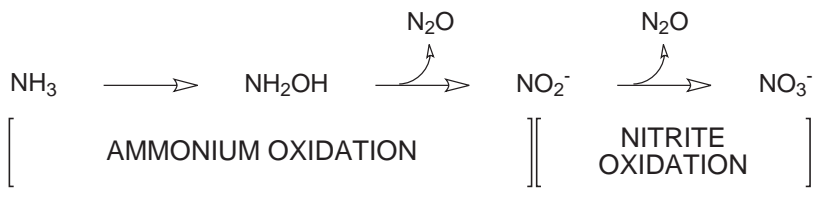

\section{DENITRIFICATION}

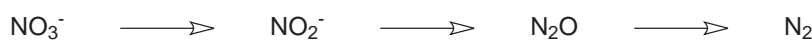

NITRIFIER DENITRIFICATION

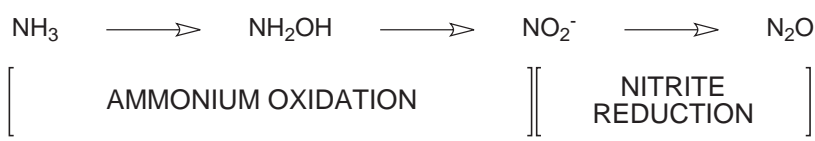

Fig. 1. Outline of different pathways of $\mathrm{N}_{2} \mathrm{O}$ production. Adapted from Wrage et al. (2001).

mechanism by which it is formed is not clear (Naqvi and Noronha, 1991; Ostrom et al., 2000). Recent works have shown that certain Archaea can also oxidize ammonium to nitrite with a metabolism similar to that of bacterial ammonium oxidation (Konneke et al., 2005). The second stage is nitrite oxidation to nitrate, with nitric oxide acting as an intermediate and possible precursor of $\mathrm{N}_{2} \mathrm{O}$. This process is carried out by organisms called nitrite-oxidizers.

Conventional denitrification is the reduction of oxidized inorganic nitrogen $\left(\mathrm{NO}_{3}^{-}, \mathrm{NO}_{2}^{-}, \mathrm{NO}, \mathrm{N}_{2} \mathrm{O}\right)$ to gaseous nitrogen forms $\left(\mathrm{N}_{2}, \mathrm{~N}_{2} \mathrm{O}\right)$, and involves a loss of fixed-nitrogen from the system. This process is carried out by several organisms as a respiration process under suboxic $\left(<0.1 \mathrm{ml} / \mathrm{L} \mathrm{O}_{2}\right)$ conditions, with nitrate as the electron acceptor (Knowles, 1982). For this reason, denitrification is enhanced in $\mathrm{O}_{2}$ minimum areas (Codispoti et al., 2001; Gruber and Sarmiento, 1997 ) or in areas where large accumulation of particulate organic matter takes place, such as the pycnocline (Alldredge and Cohen 1987). Denitrification occurs in several stages, during which $\mathrm{N}_{2} \mathrm{O}$ is an intermediate, unlike nitrification. Thus, $\mathrm{N}_{2} \mathrm{O}$ can be both produced and consumed during denitrification (Elkins et al., 1978). Under suboxic conditions $(<0.1 \mathrm{ml} / \mathrm{L}), \mathrm{N}_{2} \mathrm{O}$ produced by denitrification is almost entirely reduced to $\mathrm{N}_{2}$, whereas at the oxycline, where the $\mathrm{O}_{2}$ concentration is near $0.5 \mathrm{ml} / \mathrm{L}$, the $\mathrm{N}_{2} \mathrm{O}$ production rate significantly increases and the reduction of $\mathrm{N}_{2} \mathrm{O}$ to nitrogen is inhibited (Castro and Farías, 2004).

Moreover, certain species of nitrifying bacteria can produce $\mathrm{N}_{2} \mathrm{O}$ under $\mathrm{O}_{2}$ stress conditions $(<1 \mathrm{ml} / \mathrm{L})$ by means of ammonium oxidation to nitrite, which in turn is reduced to $\mathrm{N}_{2} \mathrm{O}$; this process is called "nitrifier denitrification" (Poth and Focht, 1985). This process is carried out by ammonium oxidizers like Nitrosomona europaea (Ritchie and Nicholas, 1972; Shaw et al., 2006). Biochemical studies show that the second part of this process indeed corresponds to denitrifica- tion, and that the involved enzymes could be the same (Poth and Focht, 1985). Otherwise, the genomes of ammonium oxidizing archaea also present nitrite reductase and nitric oxide reductase genes, potentially allowing them to carry out nitrifier denitrification (Hallam et al., 2006; Treusch et al., 2005). Figure 1 shows a general outline of these processes.

Recently, some additional processes have been recognized as a part of the marine nitrogen cycle, particularly the anammox reaction $\left(\mathrm{NO}_{2}^{-}+\mathrm{NH}_{4}^{+} \rightarrow \mathrm{N}_{2}+2 \mathrm{H}_{2} \mathrm{O}\right)$, which result in a loss of nitrogen from the system as nitrogen gas $\left(\mathrm{N}_{2}\right)$. Kartal et al. (2007) found that Kuenenia stuttgatiensis, an anammox bacterium, can produce small quantities of $\mathrm{N}_{2} \mathrm{O}$ as a byproduct of anammox.

The typical vertical distribution of $\mathrm{N}_{2} \mathrm{O}$ in the open ocean shows that it is directly correlated with nitrate and inversely correlated with $\mathrm{O}_{2}$ (Nevison et al., 2003; Oudot et al., 2002). Since nitrification is favored at low $\mathrm{O}_{2}$ concentrations (Carlucci and McNally, 1969; Goreau et al., 1980), this distribution has usually been interpreted as an indirect evidence that nitrification is the dominant process in oceanic $\mathrm{N}_{2} \mathrm{O}$ formation. Isotopic data, however, show that $\delta^{15} \mathrm{~N}\left(\mathrm{~N}_{2} \mathrm{O}\right)$ values are higher than expected for $\mathrm{N}_{2} \mathrm{O}$ produced by nitrification in areas where the relationship between $\mathrm{O}_{2}, \mathrm{~N}_{2} \mathrm{O}$, and nitrate indicates that nitrification is the dominant process (Dore et al., 1998; Kim and Craig, 1990; Naqvi et al., 1998; Ostrom et al., 2000; Yoshida, 1988; Yoshida et al., 1989).

The determination of $\mathrm{N}_{2} \mathrm{O}$ isotopomers (i.e., the intramolecular distribution of ${ }^{15} \mathrm{~N}$ in the linear NNO molecule) offers a useful and relatively new tool for elucidating $\mathrm{N}_{2} \mathrm{O}$ production mechanisms (Toyoda and Yoshida 1999). $\delta^{15} \mathrm{~N}^{\alpha}$ is the relative isotopic abundance of ${ }^{15} \mathrm{~N}$ for the central position and $\delta^{15} \mathrm{~N}^{\beta}$ for the terminal position. Site preference (SP) is defined as follows:

S.P. $=\delta^{15} \mathrm{~N}^{\alpha}-\delta^{15} \mathrm{~N}^{\beta}$

Since $\mathrm{N}_{2} \mathrm{O}$ precursors contain only one nitrogen atom $\left(\mathrm{NO}_{2}^{-}\right.$, $\mathrm{NO}, \mathrm{NH}_{2} \mathrm{OH}$ ) and excluding the possibility that different chemical species combine to form $\mathrm{N}_{2} \mathrm{O}$, the isotopomer distribution in $\mathrm{N}_{2} \mathrm{O}$ should be independent of the $\delta^{15} \mathrm{~N}$ of the precursors. It can, therefore, be determined by the biochemical reaction step in which equivalence between both nitrogen atoms is lost (Toyoda et al., 2002). This is the main advantage of the $\mathrm{N}_{2} \mathrm{O}$ isotopomer ratio over the conventional $\delta^{15} \mathrm{~N}$ ratio. Nevertheless, the lack of knowledge of the specific biochemical mechanisms involved in $\mathrm{N}_{2} \mathrm{O}$ production makes it difficult to "predict" which isotopomer signature corresponds to which particular processes (Schmidt et al., 2004). The few works that present isotopomer results in marine environments have found positive SP values associated with nitrification (Popp et al., 2002; Toyoda et al., 2002) or denitrification (Westley et al., 2006; Yamagishi et al., 2005). The main problem in interpreting these results is the context of $\mathrm{N}_{2} \mathrm{O}$ production processes and how these processes influence the isotopomer signal. 


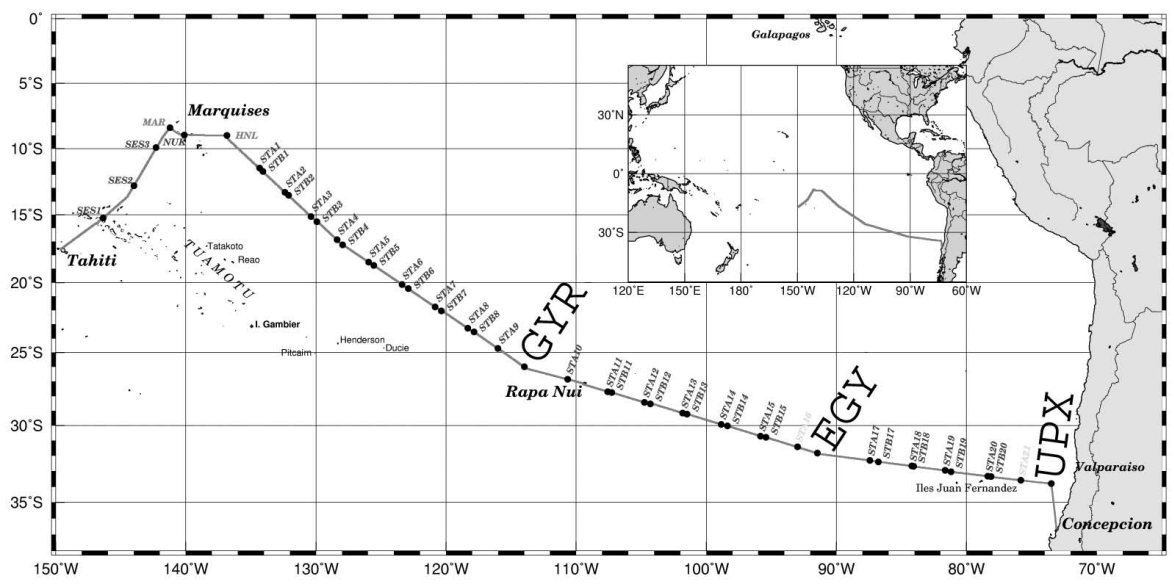

Fig. 2. Sampled stations during Biosope Cruise, GYR, EGY and UPX are indicated in bigger letters.

The South Pacific Central Gyre has been described as the most oligotrophic zone in the world ocean (Claustre and Maritorena, 2003), with an extreme nutrient $(\mathrm{N}, \mathrm{Fe})$ limitation (Bonnet et al., 2007); it is also one of the least studied areas of the ocean (Daneri and Quiñones, 2001). In contrast, the central Chile upwelling system is one of the most productive marine environments in the world, with a high supply of nitrate and other nutrients due to an upwelling regime and coastal contribution through land runoff, which supports a high rate of new production (Daneri et al., 2000). In addition, this area contains the southernmost extension of the $\mathrm{O}_{2}$ minimum zone (OMZ), fed from the equator by the Peru Chile Undercurrent (PCUC); the OMZ has a significant influence on the water column community (Morales et al., 1996). Thus, the transect stretching from the center of the gyre to the Chilean coast is an ideal area for studying the variety of processes that produce $\mathrm{N}_{2} \mathrm{O}$ along an extreme gradient.

The main objective of this work is try to elucidate the changes in $\mathrm{N}_{2} \mathrm{O}$ production processes in relation to different environmental conditions in the water column through a comparison of the different environments encountered during the BIOSOPE cruise (Fig. 2). To accomplish this, we employ a combination of isotopic and isotopomeric $\mathrm{N}_{2} \mathrm{O}$ measurements along with oceanographic and biogeochemical data.

\section{Methods}

\subsection{Sampling}

All samples were collected during the BIOSOPE cruise (October-December 2004 or early austral spring) on board the R/V L'Atalante. The stations chosen in this work - GYR $\left(26.07^{\circ} \mathrm{S}, 113.99^{\circ} \mathrm{W}\right)$, EGY $\left(31.90^{\circ} \mathrm{S}, 91.41^{\circ} \mathrm{W}\right)$, and UPX $\left(34.58^{\circ} \mathrm{S}, 72.43^{\circ} \mathrm{W}\right)$ - are representatives of different zones along the trophic gradient. GYR is within the South Pacific Central Gyre, EGY is on the eastern border of the gyre, and
UPX is in the coastal upwelling zone, $33 \mathrm{~km}$ from the shore (Fig. 2).

Temperature and salinity profiles were obtained with a Seabird SBE 911 + CTD. Fluorescence (as Relative Fluorescence Unit, RFU) was measured in situ from a Chelsea AquaTracka fluorometer, attached to the CTD rosette-sampler system. Sampling was done one hour before sunrise, with twelve-Liter Niskin bottles attached to a CTD-O rosette. Particle content was measured by an Underwater Video Profiler (UVP) system as described in Gorsky et al. (2000). Particle size was measured as Equivalent Spherical Diameter (ESD) in $\mathrm{mm}$ (Stemmann et al., 2000).

Seawater samples were collected for isotopic and $\mathrm{N}_{2} \mathrm{O}$ concentration analyses as well as for $\mathrm{O}_{2}$ and nutrient analyses. The samples for isotopes, isotopomers, and $\mathrm{N}_{2} \mathrm{O}$ analyses were transferred directly into 125 -ml glass flasks, preserved with $\mathrm{HgCl}_{2}$, and sealed with butyl rubber stoppers following the method described in Yamaghishi et al. (2001).

\subsection{Nitrous oxide, oxygen, nitrate, and phosphate determi- nation}

$\mathrm{N}_{2} \mathrm{O}$ was determined in the seawater samples used for the isotopic analysis with gas chromatography and mass spectrometry detection. The method is well described in Toyoda et al. (2005).

$\mathrm{O}_{2}$ was measured in situ with a Seabird SBE $43 \mathrm{O}_{2}$ meter. The $\mathrm{O}_{2}$ sensor was calibrated with Winkler titrations. Nitrate was immediately analyzed on board following two methods depending on the concentration range. For low concentrations (nM range), the method described in Raimbault et al. (1990) was used, whereas for higher concentrations ( $\mu \mathrm{M}$ range), the method of Armstrong et al. (1967) was used. Phosphate was analyzed immediately on board by the method described in Tréguer and LeCorre (1975). The Apparent $\mathrm{O}_{2}$ Utilization (AOU) value was obtained by subtracting the measured value of the $\mathrm{O}_{2}$ concentration from the 
saturation value computed for the temperature and salinity of the seawater (Murray and Riley, 1969), whereas the difference between the $\mathrm{N}_{2} \mathrm{O}$ saturation concentration and its measured concentration $\left(\Delta \mathrm{N}_{2} \mathrm{O}\right)$ in the seawater was used to infer its production (positive) or consumption (negative) (Yoshinari, 1976).

\subsection{Isotopic and isotopomeric determinations}

Isotopic and isotopomeric determinations were carried out at the Tokyo Institute of Technology using a Finnigan MAT 252 mass spectrometer following the method described in Toyoda and Yoshida (1999). For this, $\mathrm{N}_{2} \mathrm{O}$ was extracted from samples by sparging with helium and then introduced into a preconcentration-gas chromatography-isotopic ratio mass spectrometry system. $\delta^{15} \mathrm{~N}(\alpha$ and $\beta)$ and $\delta^{18} \mathrm{O}\left(\mathrm{N}_{2} \mathrm{O}\right)$ were determined in relation to the atmospheric nitrogen and Vienna Standard Mean Ocean Water (VSMOW), respectively. $\mathrm{N}_{2} \mathrm{O}$ isotopomers were determined based on the analysis of ionic mass fragments $\left(\mathrm{NO}^{+}\right.$and $\mathrm{N}_{2} \mathrm{O}^{+}$) formed by the electronic impact of $\mathrm{N}_{2} \mathrm{O}$. This determination was possible since $\mathrm{NO}^{+}$fragments contain the central nitrogen $(\alpha)$, which allows the conversion of the fragment ratios into isotopic ratios of ${ }^{14} \mathrm{~N}^{15} \mathrm{NO}$ and ${ }^{15} \mathrm{~N}^{14} \mathrm{NO}$. Although there is a rearrangement reaction during the ionic fragmentation process, its magnitude can be determined and corrections applied. Precision of the measurements is typically better than $0.5 \%$ o for $\delta^{15} \mathrm{~N}_{\text {bulk }}$ and $\delta^{18} \mathrm{O}$, and better than $1 \%$ for $\delta^{15} \mathrm{~N}^{\alpha}$ and $\delta^{15} \mathrm{~N}^{\beta}$ (Toyoda et al., 2005). Isotopomeric ratios were calculated with the following expressions:

$$
\begin{aligned}
{ }^{15} \mathrm{R}^{\alpha} & =\frac{\left[{ }^{14} \mathrm{~N}^{15} \mathrm{~N}^{16} \mathrm{O}\right]}{\left[{ }^{14} \mathrm{~N}^{14} \mathrm{~N}^{16} \mathrm{O}\right]} \\
{ }^{15} \mathrm{R}^{\beta} & =\frac{\left[{ }^{15} \mathrm{~N}^{14} \mathrm{~N}^{16} \mathrm{O}\right]}{\left[{ }^{14} \mathrm{~N}^{14} \mathrm{~N}^{16} \mathrm{O}\right]} \\
\delta^{15} \mathrm{~N}^{\alpha} & =\left\{\frac{{ }^{15} \mathrm{R}^{\alpha}}{{ }^{15} \mathrm{R}^{\alpha}(\mathrm{std})-1}\right\} \times 1000 \\
\delta^{15} \mathrm{~N}^{\beta} & =\left\{\frac{{ }^{15} \mathrm{R}^{\beta}}{{ }^{15} \mathrm{R}^{\beta}(\mathrm{std})-1}\right\} \times 1000
\end{aligned}
$$

Furthermore, the definition of $\delta^{15} \mathrm{~N}_{\text {bulk }}=\left(\delta^{15} \mathrm{~N}^{\alpha}+\delta^{15} \mathrm{~N}^{\beta}\right) / 2$ allowed us to compare the relative abundance of the isotopomers $\alpha$ and $\beta$ with the relative isotopic abundance of ${ }^{15} \mathrm{~N}$.

\subsection{Data analysis}

The Brunt-Vaisälä frequency (BVF) was determined using temperature and salinity data. For better data interpretation, BVF profiles were visually fitted to an eightterm Gaussian model included in MATLAB software. The mixed layer was determined by averaging the depths of four criteria as described in the official data source of the Biosope cruise (http://www.obs-vlfr.fr/proof/php/bio log_basicfiles.php). The photic layer is defined as the depth at which the surface light irradiance is reduced to $1 \%$ of its surface value. This determination was made by averaging readings from four different sensors.

\section{Results and discussion}

\subsection{General water column characteristics}

The three studied stations are located along a gradient from very oligotrophic to highly eutrophic systems and are found in different oceanographic regimes with the following characteristics. The GYR station is located at the center of South Pacific Gyre, with severe oligotrophy (Claustre and Maritorena, 2003). The fluorescence peak ( $0.23 \mathrm{RFU})$ at this station occurs at $\sim 180 \mathrm{~m}$, just below the bottom of the photic layer $(164 \mathrm{~m})$. The shallower pycnocline is located at $10 \mathrm{~m}$. A second, thicker pycnocline is observed between 100 and $500 \mathrm{~m}$, as shown by the BVF plot in Fig. 3a.

The EGY station is located on the eastern border of the South Pacific Gyre, in a less oligotrophic environment. The fluorescence peak $(0.34 \mathrm{RFU}$ at $52 \mathrm{~m})$ is shallower and more pronunced than at the previous station, well above the depth of the photic layer $(92 \mathrm{~m})$. The shallower pycnocline is located at $26 \mathrm{~m}$ and the BVF plot shows a second, thicker pycnocline between 120 and $400 \mathrm{~m}$ (Fig. 3b). Both GYR and EGY stations are located in a zone in which surface and subsurface waters $(0-500 \mathrm{~m})$ are mainly dominated by East South Pacific Central Water (ESPCW), which is characterized by wide temperature and salinity ranges. The ESPCW is formed in the middle of the South Pacific close to $40^{\circ} \mathrm{S}$ (Emery and Meincke 1986).

The UPX station is located off the coast of central Chile in a highly productive environment. The chlorophyll fluorescence peak ( $0.81 \mathrm{RFU})$ at this station is found at $32 \mathrm{~m}$, but fluorescence is still high at the surface $(0.70 \mathrm{RFU})$. The peak is close to the base of the photic layer $(37 \mathrm{~m})$ and the mixed layer $(36 \mathrm{~m})$. The BVF plot showed a high stability zone from 20 to $60 \mathrm{~m}$ depth (Fig. 3c). Changes in the values and shapes of the chlorophyll profiles from west to east clearly showed the expected differences in productivity due to the enhanced nutrient supply. The central Chile coast is characterized by the upwelling of nutrient-rich, low $\mathrm{O}_{2}$ Equatorial Subsurface Water (ESSW) (Strub et al., 1995).

Circulation at this coastal station is greatly affected by horizontal advection that brings nutrient-enriched waters to this latitude in the form of ESSW, which is transported by the PCUC. Indeed, the PCUC has been detected as far south as $48^{\circ} \mathrm{S}$ (Silva and Neshyba, 1979). The SW wind stress on the surface layer causes upwelling of nutrient-rich, lowoxygen waters followed by increased productivity that provides favourable conditions for $\mathrm{N}_{2} \mathrm{O}$ production (Cornejo 


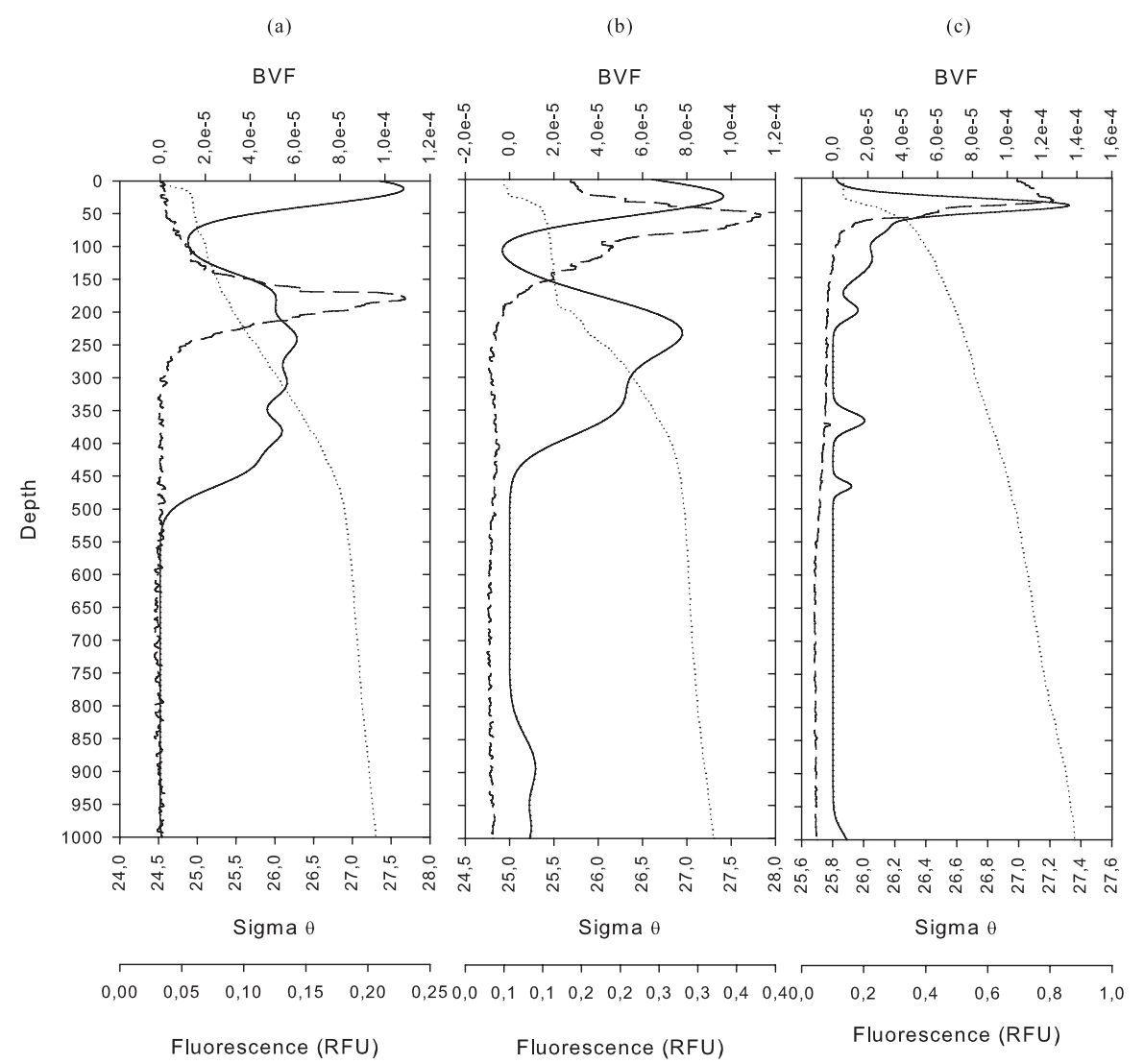

Fig. 3. Vertical profiles at stations (a): GYR, (b): EGY and (c): UPX. The parameters shown are: Potential density (dotted line), BruntVaisälä frecuency (continuous line), and Fluorescence (dashed line).

et al., 2006). Thus, $\mathrm{N}_{2} \mathrm{O}$ produced in subsurface waters is brought to the surface through advection and mixing, enhancing $\mathrm{N}_{2} \mathrm{O}$ fluxes to the atmosphere.

\subsection{Nitrous oxide, oxygen, and nutrient behavior}

Vertical distributions of $\mathrm{N}_{2} \mathrm{O}$ and $\mathrm{O}_{2}$ are shown in Fig. 4. $\mathrm{N}_{2} \mathrm{O}$ is slightly oversaturated at GYR and EGY from the surface to $\approx 200 \mathrm{~m}(\approx 114 \%$ and $\approx 105 \%$, respectively $)$, and is highly oversaturated below this depth $(\approx 230 \%$, at both stations) (Figs. 4a, b). $\mathrm{N}_{2} \mathrm{O}$ profiles at GYR and EGY are almost mirrored by the $\mathrm{O}_{2}$ profiles, indicating that the amount of $\mathrm{N}_{2} \mathrm{O}$ produced in the water column is strongly driven by the $\mathrm{O}_{2}$ concentration. At the UPX station, the whole water column is highly $\mathrm{N}_{2} \mathrm{O}$-oversaturated from $230 \%$ at the surface to $480 \%$ at the $\mathrm{N}_{2} \mathrm{O}$ maximum at $350 \mathrm{~m}$. At this station, the $\mathrm{O}_{2}$ concentrations display a strong depletion up to $\approx 10 \mu \mathrm{mol} / \mathrm{Kg}$ between $150 \mathrm{~m}$ and $300 \mathrm{~m}$ and do not show a clear relationship with the $\mathrm{N}_{2} \mathrm{O}$ profile.

Nitrate and phosphate profiles are shown in Fig. 5. At the GYR and EGY stations, both nutrients have very similar profiles, with low concentrations in the first $200 \mathrm{~m}$. Below this depth, the nitrate concentrations gradually increase to $40 \mu \mathrm{mol} / \mathrm{Kg}(1000 \mathrm{~m})$ at $\mathrm{GYR}$ and $35 \mu \mathrm{mol} / \mathrm{Kg}(400 \mathrm{~m})$ at EGY. At both stations (GYR, EGY), abrupt increases in nitrate and phosphate concentrations close to $400 \mathrm{~m}$ coincide with maxima in the $\mathrm{N}_{2} \mathrm{O}$ concentrations, suggesting an increase in the rate of nitrification at this depth. At the UPX station, nitrate concentrations are high at the surface (Fig. 5c) due to the upwelling of nutrient-rich water (Daneri et al., 2000). Although the nitrate and phosphate profiles show similar trends, the profiles appear to be more complicated than at the oceanic stations. $\mathrm{N}_{2} \mathrm{O}$ and nitrate show very similar profiles at this station, suggesting that the $\mathrm{N}_{2} \mathrm{O}$ productionconsumption processes are the same as for nitrate.

The $\mathrm{PO}_{4}^{-3}$ vs $\mathrm{NO}_{3}^{-}$plots (Figs. 5a, b, insets) suggest that at stations GYR and EGY both nutrients behave according to the Redfield ratio, indicating that nitrogen oxidative processes are predominant. At UPX, the plot (Fig. 5c, inset) suggests nitrate removal by denitrification since there is a phosphate excess in relation to nitrate according to the Redfield ratio.

In order to obtain information about the processes involved in $\mathrm{N}_{2} \mathrm{O}$ cycling throughout the water column, scatter diagrams of AOU vs. $\Delta \mathrm{N}_{2} \mathrm{O}$ and $\mathrm{AOU}$ vs. $\mathrm{NO}_{3}^{-}$below the photic layer $(200-600 \mathrm{~m})$ at GYR and EGY are presented (Figs. 6a, b). $\Delta \mathrm{N}_{2} \mathrm{O}$ correlated positively with $\mathrm{AOU}$ at both 
(a)

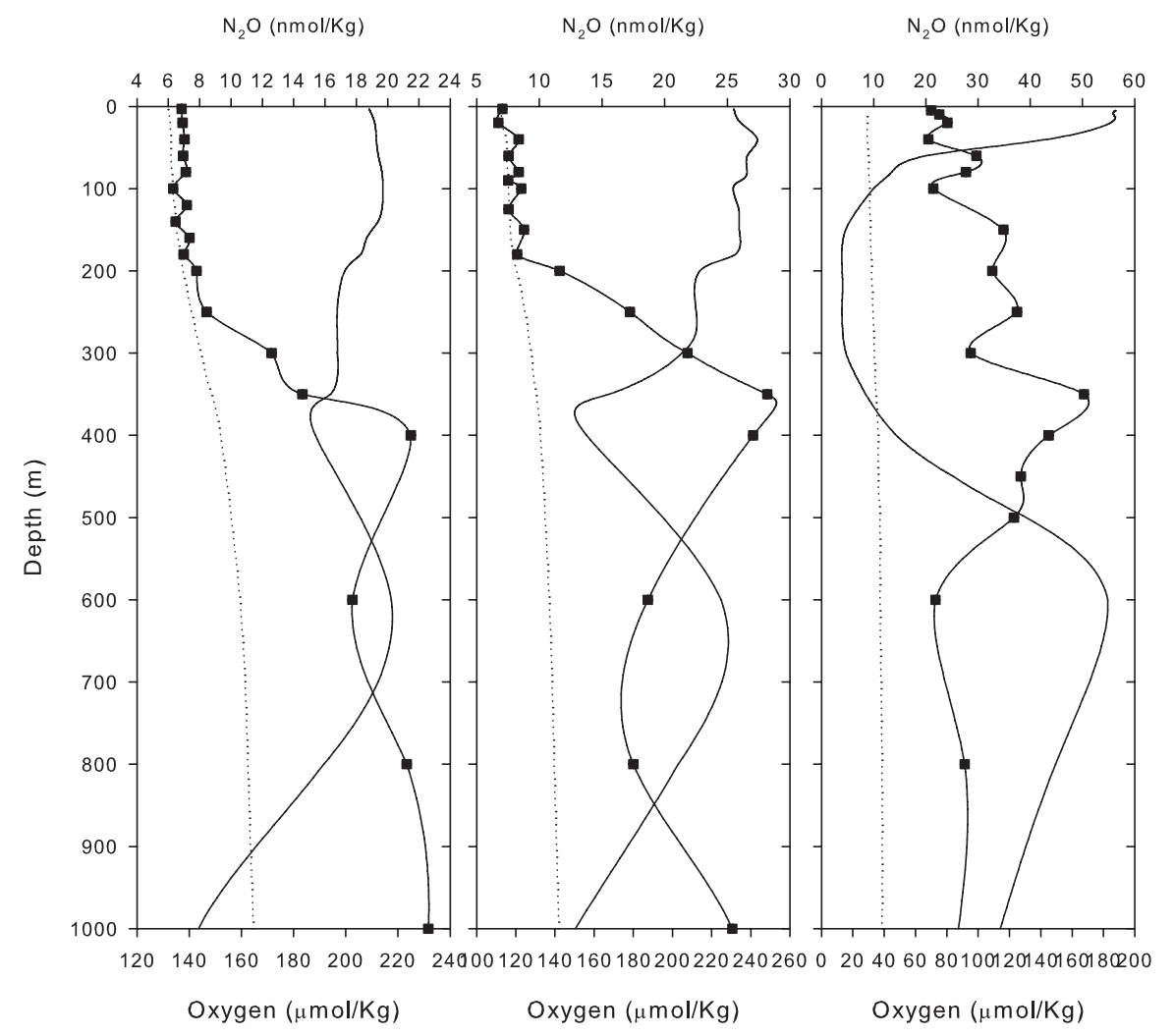

Fig. 4. Vertical profiles at stations (a): GYR, (b): EGY (c): UPX. The parameters shown are: $\mathrm{N}_{2} \mathrm{O}$ saturation (dotted line), $\mathrm{N}_{2} \mathrm{O}$ (squares) and $\mathrm{O}_{2}$ (continuous line).

stations, indicating that more $\mathrm{N}_{2} \mathrm{O}$ is produced while $\mathrm{O}_{2}$ is consumed. $\mathrm{NO}_{3}^{-}$also correlated positively with $\mathrm{AOU}$, supporting the view that, $\mathrm{N}_{2} \mathrm{O}$ and nitrate production are produced mainly from nitrification. The ratio of $\mathrm{N}_{2} \mathrm{O}$ production to $\mathrm{O}_{2}$ consumption (on a molar basis), referred to as the $\mathrm{N}_{2} \mathrm{O}$ oxidative ratio, was $1.76 \times 10^{-4}$ and $1.42 \times 10^{-4}$ for GYR and EGY station respectively. Since $\mathrm{NO}_{3}^{-}$regeneration was also linearly related to $\mathrm{AOU}$, it was possible to calculate the ratio of $\mathrm{N}_{2} \mathrm{O}$ production to $\mathrm{NO}_{3}^{-}$production (expressed as a percentage on the mol-N basis) as $0.088 \%$ and $0.15 \%$ for GYR and EGY stations respectively. The $\mathrm{N}_{2} \mathrm{O}$ oxidative ratio (i.e., produced $\mathrm{N}_{2} \mathrm{O}$ per mol of respired $\mathrm{O}_{2}$ ) and the $\mathrm{N}_{2} \mathrm{O}$ reaction yields (i.e., produced $\mathrm{N}_{2} \mathrm{O}$ per mol of produced $\mathrm{NO}_{3}^{-}$) are close to the oceanic values reported by Cohen and Gordon (1979) for the North East Pacific.

\section{$3.3 \delta^{15} \mathrm{~N}_{\text {bulk }}, \delta^{18} \mathrm{O}$, and isotopomers of nitrous oxide}

The $\delta^{15} \mathrm{~N}_{\text {bulk }}$ has been defined as equivalent to conventional $\delta^{15} \mathrm{~N}$ (Toyoda and Yoshida 1999). Surprisingly, variations of this parameter at the three stations are relatively small. In contrast, the SP signal shows great variability, which provides more information about the processes occurring in the water column. At the GYR and EGY stations, the SP values in the mixed layer are close to the expected atmospheric $\mathrm{N}_{2} \mathrm{O}$ value $(19 \pm 2 \%$ ) (Yoshida and Toyoda, 2000), indicating that surface $\mathrm{N}_{2} \mathrm{O}$ originates mainly from ocean-atmosphere interactions (Figs. 7a, b). At UPX, however, the SP value in the mixed layer $(\approx 14 \%$ ) is lower than in the air, indicating the influence of $\mathrm{N}_{2} \mathrm{O}$ upwelled with subsurface waters (Fig. 7c). Although the accepted value for the $\mathrm{SP}$ of atmospheric $\mathrm{N}_{2} \mathrm{O}$ was determined in air samples from the North West Pacific, the high mixing rates of tropospheric gases and the high residence times of atmospheric $\mathrm{N}_{2} \mathrm{O}$ over 120 years (Liao et al., 2004) make the value given by Yoshida and Toyoda (2000) a good approximation.

Site preference between the shallow pycnocline and the base of the photic layer shows high variability. Assimilatory nitrate reduction has been mentioned as a source of $\mathrm{N}_{2} \mathrm{O}$ in surface waters (Oudot et al., 1990). However, not enough information is available to establish whether this process is actually occurring. At UPX, where the mixed layer coincides with the photic layer, SP and $\delta^{18} \mathrm{O}\left(\mathrm{N}_{2} \mathrm{O}\right)$ values over the pycnocline are quite stable.

Below the photic zone, SP profiles at GYR and EGY show conspicuous minima $(11.5 \%$ o $8.5 \%$ ) at $350 \mathrm{~m}$ and $250 \mathrm{~m}$, respectively, followed by a gradual increase up to $22 \%$ in 
(a)

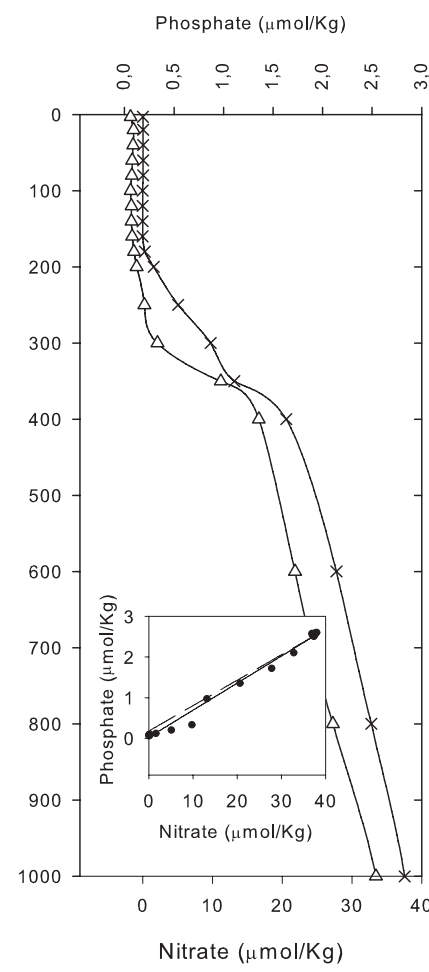

(b)

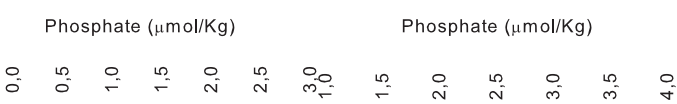

(c)

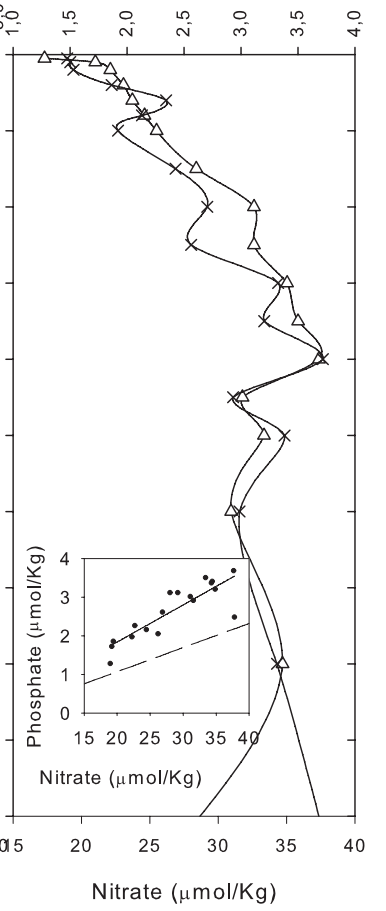

Fig. 5. Vertical profiles at stations (a): GYR, (b): EGY (c): UPX. The parameters shown are: Nitrate (cross) and phosphate (open triangle). Insets shows nitrate v/s phosphate ratio. Solid line shows linear regression of data, dashed line shows the equation deduced from Redfield $\mathrm{N}: \mathrm{P}$ ratio (16:1) (Gruber and Sarmiento, 1997).

deeper waters. Such a minimum is also observed at UPX at a very shallow depth $(40 \mathrm{~m})$ within the upper pycnocline. Below the pycnocline, SP values do not show a clear depth trend. Since SP is independent from the $\delta^{15} \mathrm{~N}$ of its precursors, or the extent of the reaction, and is only dependant on the reaction mechanism, the observed changes in SP in the water column must be associated with changes in the mechanistic sources of $\mathrm{N}_{2} \mathrm{O}$ (Toyoda et al., 2002). The SP minima at oceanic and coastal stations must be influenced by a particular process that produces low $\mathrm{SP}_{2} \mathrm{O}$.

It is unlikely that the SP minimum values are being transported from nutrient-rich coastal waters. The Ekman transport in east oceanic margins is determined by the Rossby radius of deformation, whose maximum reach at mid-latitudes is 200 to $300 \mathrm{~km}$ for very unstratified coastal waters (Csanady, 1982). Otherwise, as has been previously mentioned, surface and subsurface waters $(0-500 \mathrm{~m})$ of the Subtropical South Pacific Gyre are dominated by ESPCW, produced close to $40^{\circ} \mathrm{S}$ (Emery and Meincke, 1986).

The coincidence that all SP minima (at three stations) with high density gradient layers (see Figs. 3, 7) where particles are likely to accumulate indicates that $\mathrm{N}_{2} \mathrm{O}$ production at this point should be, at least in part, associated with the accumulation of such particles. Studies have demon- strated that temporal oxygen-depleted microsites are possible in marine snow in the absence of light (Alldredge and Cohen, 1987; Ploug, 2001; Ploug et al., 1997). The $\mathrm{O}_{2}$ consumption around sinking particles strongly depends on the advection-diffusion balance driven by sinking velocities (Csanady, 1986; Kiørboe et al., 2001), with higher $\mathrm{O}_{2}$ depletion associated with slower-falling particles.

Although the stations GYR and EGY are located in a very oligotrophic area, the accumulation of sinking particles at the steepest density gradient layer inside the pycnocline (see Brunt-Vaisälä frequency plots, Fig. 3) should allow the formation of aggregates suitable for nitrogen reductive processes, as proposed by Yoshida et al. (1989). Figure 8 shows the particle count between $0.052 \mathrm{~mm}$ and $8.438 \mathrm{~mm}$ of ESD (a wide range of marine snow sizes) at three sampled stations (C. Gorsky and M. Picheral, personal communication). At the GYR and EGY stations, small particle accumulation is observed at $300 \mathrm{~m}(\approx 35 \mathrm{part} / \mathrm{L})$ and $50 \mathrm{~m}(\approx 45 \mathrm{part} / \mathrm{L})$, respectively, roughly coincident with high stability zones. The particle content at EGY below the photic zone shows no significative accumulation; the mean particle content between $200 \mathrm{~m}$ and $400 \mathrm{~m}$ is $\approx 22 \mathrm{part} / \mathrm{L}$. High particle contents at the UPX station are also closely related to the stability profile.

Toyoda et al. (2002) proposed that nitrification should 
(a)

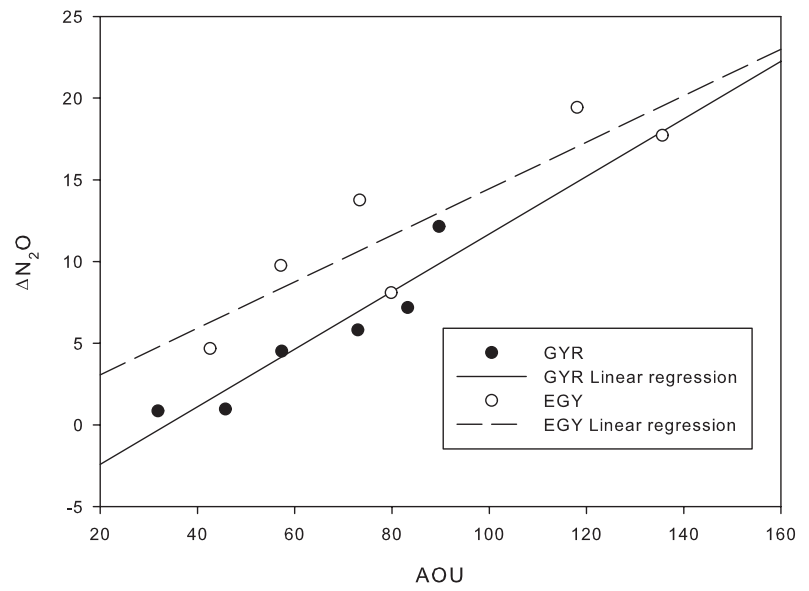

(b)

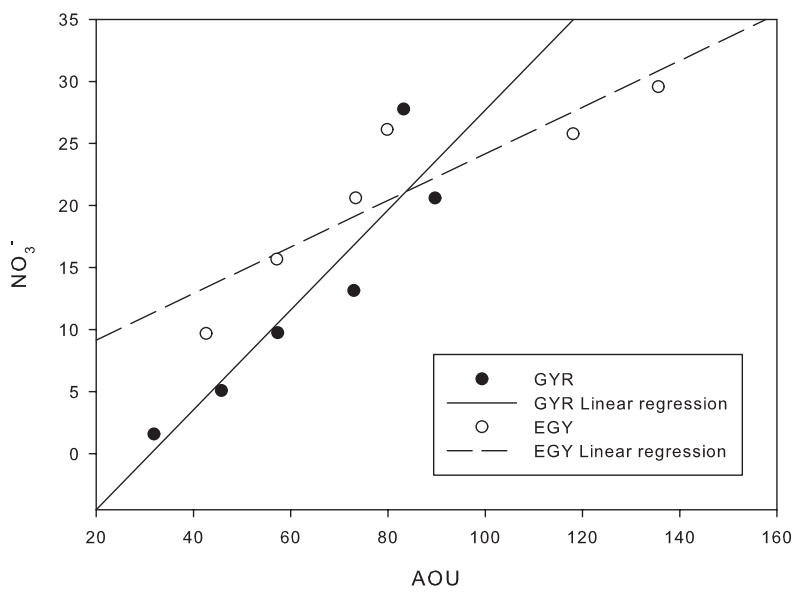

Fig. 6. (a) $\mathrm{AUO} v / \mathrm{s} \Delta \mathrm{N}_{2} \mathrm{O}$ at GYR and EGY stations from 200 to $600 \mathrm{~m}$, the linear regression model for each line was GYR: $y=-$ 5.94+0.176 x, $\mathrm{r}^{2}=0.87$; EGY: $\mathrm{y}=0.22+0.142 \mathrm{x}, \mathrm{r}^{2}=0.79$. (b) $\mathrm{AUO}$ $\mathrm{v} / \mathrm{s} \mathrm{NO}_{3}^{-}$at GYR and EGY stations from 200 to $600 \mathrm{~m}$, the linear regression model for each line was GYR: $y=-12.0+0.403 \mathrm{x}, \mathrm{r}^{2}=0.85$; EGY: $\mathrm{y}=5.4+0.188 \mathrm{x}, \mathrm{r}^{2}=0.81$.

yield $\delta^{15} \mathrm{~N}^{\alpha}$ enriched $\mathrm{N}_{2} \mathrm{O}$ due to the existence of a hyponitrite (-ONNO-) intermediary followed by the selective breakage of the NO bond where the lightest isotopes are located, based on the ZPE (zero point energy) for $\mathrm{N}_{2} \mathrm{O}$ (Zuñiga et al., 2003). This mechanism has been described for some nitric oxide reductases (Hendriks et al., 2000; Wasser et al., 2002). Culture experiments carried out by Sutka et al. (2006) show that ammonium oxidation carried out by ammonium oxidizers (i.e. Nitrosomona europaea, Nitrosospira multiformis) produces $\mathrm{N}_{2} \mathrm{O}$ enriched in $\delta^{15} \mathrm{~N}^{\alpha}$, with average SP values of $33 \%$. Despite the lack of conclusive evidence about this specific mechanism in nitrification, if we assume that nitrification is the main process of $\mathrm{N}_{2} \mathrm{O}$ production, at least at the oceanic stations, positive SP values below the photic layer can be attributed to nitrification.
These results, as well as other culture experiments carried out by Sutka et al. $(2003,2006)$ show that, under $\mathrm{O}_{2}$ stress, nitrifier denitrification mediated by ammonium oxidizers (i.e. Nitrosomona europaea and Nitrosospira multiformis), produces $\mathrm{N}_{2} \mathrm{O}$ with an average $\mathrm{SP}$ value of zero. This means that there is no selectivity of nitrogen atoms during $\mathrm{N}_{2} \mathrm{O}$ production. Evidence of sequential mechanisms of $\mathrm{N}_{2} \mathrm{O}$ production by nitrite reductive processes in bacteria has been reported several times in the biochemical literature (Aerssens et al., 1986; Averill and Tiedje, 1982; WeegAerssens et al., 1988; Zafiriou et al., 1989). Such mechanisms involve the successive addition of one molecule of precursor $\left(\mathrm{NO}_{2}^{-}\right.$or $\left.\mathrm{NO}\right)$ to the enzyme. The resulting ${ }^{15} \mathrm{~N}$ distribution must be statistically determined by the entrance of the precursor, contrary to the selective effect of simultaneous mechanisms proposed by Toyoda et al. (2002).

Although it has been pointed out that nitrifier denitrification occurs under $\mathrm{O}_{2}$ stress, Shaw et al. (2006) demonstrated that bacteria of the genera Nitrosospira and Nitrosomona are capable of producing $\mathrm{N}_{2} \mathrm{O}$ via nitrifier denitrification in the presence of nitrite, even in aerobic environments. Nitrifier denitrification has not been studied in marine environments, and its possible ecological role is far from being established. Wrage et al. (2001) proposed thermodynamic reasons for the occurrence of nitrifier denitrification due to the negative Gibbs free energy for the $\mathrm{NH}_{4}^{+} \rightarrow \mathrm{NO}_{2}^{-} \rightarrow \mathrm{N}_{2} \mathrm{O}$ processes, which are favoured at low pH. Poth and Focht (1985) have proposed that nitrifier denitrification in soil can act as a nitrite detoxification mechanism. Nitrite has been shown to be toxic for ammonium oxidizers since it reduces ammonium monooxygenase activity (Stein and Arp, 1998). Therefore, we propose that nitrite accumulation around sinking particles due to the sudden loss of speed in the pycnocline potentially activates nitrifier denitrification enzymes on ammonium oxidizers.

It is important to emphasize that $\delta^{15} \mathrm{~N}^{\alpha}$ enrichment due to denitrifying $\mathrm{N}_{2} \mathrm{O}$ consumption in anoxic microsites of particles in oceanic environments, as previously pointed out (Yoshida et al., 1989), is not expected because $\mathrm{N}_{2} \mathrm{O}$ reduction only occurs at very low $\mathrm{O}_{2}$ concentrations (Castro and Farías, 2004; Elkins et al., 1978). Very large aggregates are necessary for the occurrence of highly anoxic microsites in particles and this is unlikely in open oligotrophic or even mesotrophic environments. If this process occurs, its effect must be negligible.

$\delta^{18} \mathrm{O}\left(\mathrm{N}_{2} \mathrm{O}\right)$ is always hard to elucidate due to its dependence on the isotopic signature of precursors. The $\delta^{18} \mathrm{O}$ $\left(\mathrm{N}_{2} \mathrm{O}\right)$ profile below the mixed layer at GYR and EGY and below $500 \mathrm{~m}$ at UPX are similar in shape to the SP, as previously observed by Toyoda et al. (2002) and Popp et al. (2002), indicating that $\delta^{18} \mathrm{O}\left(\mathrm{N}_{2} \mathrm{O}\right)$ is also driven by $\mathrm{N}_{2} \mathrm{O}$ production mechanisms. The primary source of $\mathrm{O}$ in the $\mathrm{N}_{2} \mathrm{O}$ produced by ammonium oxidation is dissolved $\mathrm{O}_{2}$ (Ostrom et al., 2000), since it is expected that $\delta^{18} \mathrm{O}\left(\mathrm{N}_{2} \mathrm{O}\right)$ will be greater than $40 \%$ o. Furthermore, the preferential breakage of 
(a)

$\delta^{15}$ N, S.P. $(\%)$

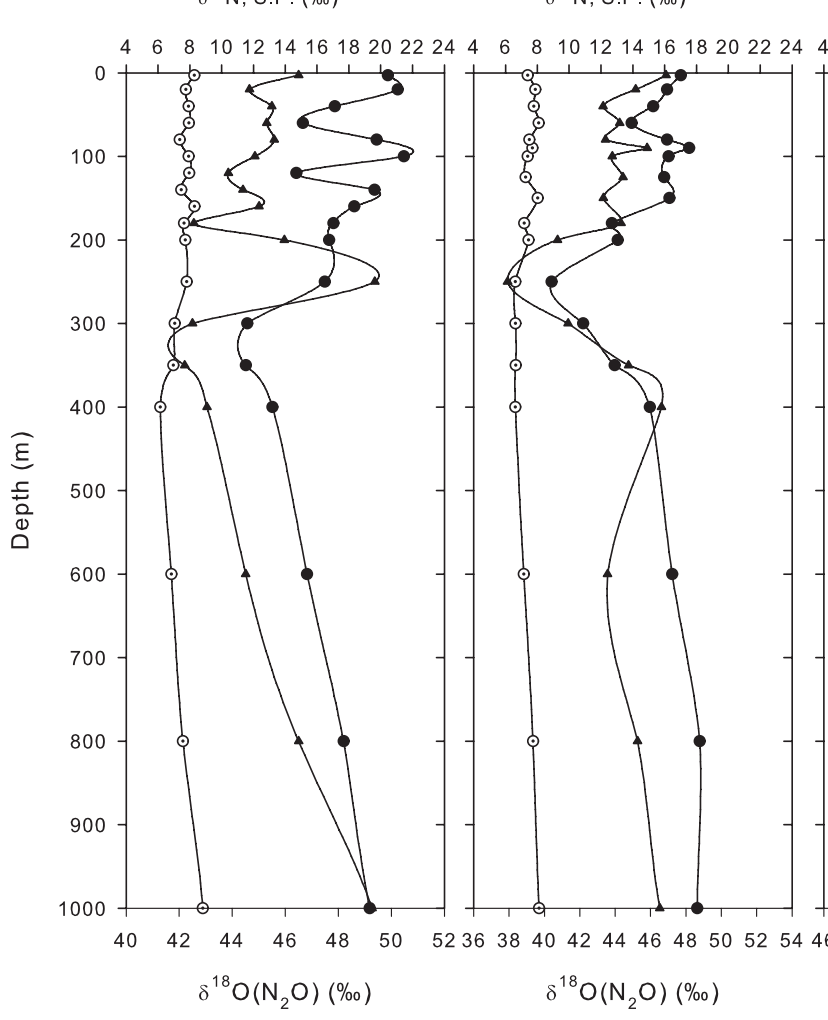

(c)

$\delta^{15} \mathrm{~N}$, S.P. $(\%)$

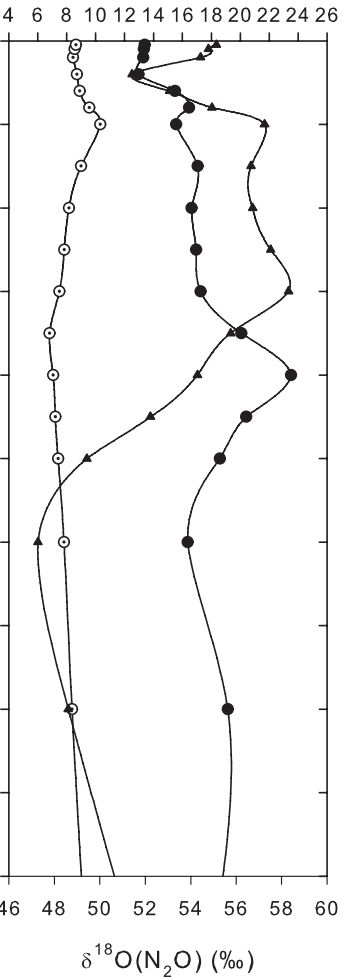

Fig. 7. Vertical profiles at stations (a): GYR, (b): EGY (c): UPX. The parameters shown are: $\delta^{15} \mathrm{~N}_{\text {bulk }}$, (open circle): Site preference (solid circle), $\delta^{18} \mathrm{O}\left(\mathrm{N}_{2} \mathrm{O}\right)$ (solid triangle).

bonds of the lightest isotopes during the intermediate hyponitrile step should drive the $\delta^{18} \mathrm{O}\left(\mathrm{N}_{2} \mathrm{O}\right)$, as occurs with ${ }^{15} \mathrm{~N}^{\alpha}$ enrichment (Schmidt et al., 2004). The source of the oxygen atom in $\mathrm{N}_{2} \mathrm{O}$ produced by nitrite reduction is nitrite (Aerssens et al., 1986; Averill, 1996). Therefore, if this (nitrite) is produced in situ by ammonium oxidizers, it must be isotopically depleted compared to ammonium and $\mathrm{O}_{2}$. Thus, the resulting $\mathrm{N}_{2} \mathrm{O}$ must be depleted in ${ }^{18} \mathrm{O}$. This explains why $\delta^{18} \mathrm{O}\left(\mathrm{N}_{2} \mathrm{O}\right)$ is lighter in the deeper pycnocline, even when dissolved $\mathrm{O}_{2}$ should be isotopically enriched due to the respiration of organic matter accumulated in this pycnocline, supporting nitrifier denitrification hypotheses as a $\mathrm{N}_{2} \mathrm{O}$ source in these regions.

The behavior of SP and $\delta^{18} \mathrm{O}\left(\mathrm{N}_{2} \mathrm{O}\right)$ below the pycnocline at UPX is more complicated than at the oceanic stations. Maximum values of $\delta^{18} \mathrm{O}\left(\mathrm{N}_{2} \mathrm{O}\right)$ between $56 \%$ and $60 \%$ coincide with the $\mathrm{O}_{2}$ minimum zone (OMZ). This can be interpreted as the influence of the isotopic enrichment of $\mathrm{O}_{2}$ due to respiration. From this, it can be concluded that the main source of $\mathrm{N}_{2} \mathrm{O}$ is nitrification. Otherwise, $\mathrm{SP}$ in the $\mathrm{OMZ}$ $\left(\approx 17 \%\right.$ o) is diminished related to the $\mathrm{N}_{2} \mathrm{O}$ released by nitrification at the oceanic station $(\approx 22 \%$ o), probably due to the influence of nitrifier denitrification. In any case, these two processes could be running simultaneously. The SP maximum is observed at $400 \mathrm{~m}$, coinciding with the nitrate maximum and the rising $\mathrm{O}_{2}$ concentration below the OMZ, and slightly deeper than the $\mathrm{N}_{2} \mathrm{O}$ maximum $\left(50.29 \mathrm{nmol} \mathrm{Kg}^{-1}\right)$. This suggests an enhancement of the extent of nitrification at this depth. It must be considered that the coastal zone is a highly dynamic environment, with significant meridional transport and isotopic, isotopomeric, and concentration values that could be influenced by non-local processes. In fact, minima of $\delta^{18} \mathrm{O}\left(\mathrm{N}_{2} \mathrm{O}\right), \mathrm{SP}$, and $\mathrm{N}_{2} \mathrm{O}$ are found at UPX $(600 \mathrm{~m})$, as is an $\mathrm{O}_{2}$ maximum; this parameter seems to be related to the core of a water mass identified at this depth $\left(\mathrm{S} \approx 34.3\right.$ and $\left.\mathrm{T} \approx 5.5^{\circ} \mathrm{C}\right)$.

\subsection{Contribution of nitrifier denitrification}

At GYR and EGY, it is possible to identify at least 3 sources of $\mathrm{N}_{2} \mathrm{O}$ according to the shape of the SP profiles. A first source can be attributed to mixing with the air in the shallow mixed layer, where the average SP at both stations is about $17 \%$, slightly below the value expected for the atmosphere $(19 \pm 2 \%$ ) (Yoshida and Toyoda, 2000). A second source is represented by the SP signal below $1000 \mathrm{~m}$, which averaged $22 \%$, and a third source is located at the SP minimum 


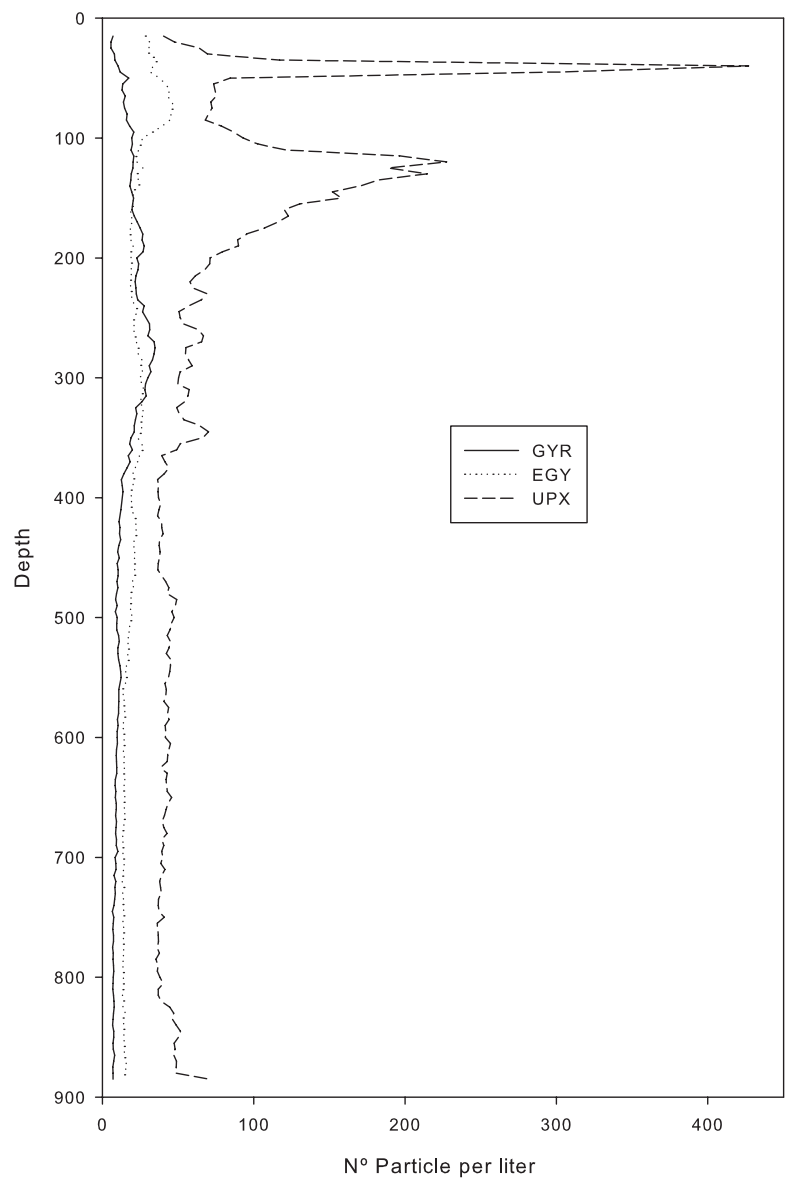

Fig. 8. Particle content at the stations : GYR (continuous line), EGY (dotted line) and UPX (dashed line).

located at $320 \mathrm{~m}$ and $250 \mathrm{~m}$ at the GYR and EGY stations, respectively.

Assuming that there is no significant contribution from airsea transfer below the pycnocline, and that SP values below $1000 \mathrm{~m}$ are representative only of ammonium oxidation, it is possible to build a simple two-box model to elucidate the contribution of ammonium oxidation and nitrite reduction to the minimum SP zone at GYR and EGY using SP values. The fraction of $\mathrm{N}_{2} \mathrm{O}$ produced by nitrifier denitrification $(F)$ can be determined as follows:

$F=\frac{S P_{I M}-S P_{a o}}{S P_{n r}-S P_{a o}}$

where $S P_{I M}$ is the SP value at the site preference minimum, $S P_{a o}$ is the SP value attributable to ammonium oxidation (equal to the SP value below $1000 \mathrm{~m}$ ), and $S P_{n r}$ is the $\mathrm{SP}$ value attributable to nitrite reduction, equal to zero, based on the biochemical literature discussed above, and the values obtained in cultures with induced nitrifier denitrification (Sutka et al., 2004; Sutka et al., 2006). The assumption that
SP values below $1000 \mathrm{~m}$ are representative of nitrification is supported by the $\delta^{15} \mathrm{~N}^{\alpha}$ enrichment predicted for this process and the agreement of the nitrate-phosphate ratio with the Redfield ratio for those stations shown in Fig. 5. If we assume that our hypothesis about $\mathrm{N}_{2} \mathrm{O}$ production through nitrifier denitrification is correct, the calculated $F$ values of 0.4 and 0.5 (GYR and EGY, respectively) indicate that nitrifier denitrification pathways can be an important source of $\mathrm{N}_{2} \mathrm{O}$, even in oligotrophic and well-oxygenated waters.

At UPX, the $\mathrm{N}_{2} \mathrm{O}$ production processes seems to be more complicated than at the oceanic stations. Coastal environments are commonly highly dynamic and highly influenced by horizontal advection. Because of this, the model applied here to the oceanic station should not be valid for the coastal station. Nevertheless, nitrifier denitrification could be an important source of $\mathrm{N}_{2} \mathrm{O}$ to the atmosphere, in view of the SPdepleted $\mathrm{N}_{2} \mathrm{O}$ present in the mixed layer (related to the expected atmospheric SP values).

\section{Conclusions and perspectives}

Our results show that $\mathrm{N}_{2} \mathrm{O}$ sources in the ocean are far from being identified. Even in very stable oligotrophic environments, different mechanisms could coexist. In this sense, new tools like $\mathrm{N}_{2} \mathrm{O}$ isotopomer determination provide new information about nitrogen cycling processes.

The SP signal supporting the evidence of the occurrence of nitrifier denitrification in highly oligotrophic environments is one of the most striking contributions of this work. Particular chemical dynamics of this process under such conditions, as well the role of particles should be the subject of further challenging studies.

The importance of the occurrence of nitrifier denitrification in oceanic environments for the whole nitrogen cycle may be enormous, considering that the Central South Pacific Gyre represents a major part of the South Pacific. Moreover, such conditions are found in the other oceans, thus rendering this process a potentially significant contributor to the oceanic $\mathrm{N}_{2} \mathrm{O}$ budget.

Acknowledgements. Dominique Tailliez and Claudie Bournot are warmly thanked for their efficient help in CTD rosette management and data processing. The authors thank G. Gorsky and M. Picheral for allowing us to use their UVP data; O. Ulloa, G. Alarcon, M. Gallegos, and the crew of the R. V. L'Atalante for their help during the BIOSOPE Cruise. J. Charpentier thanks V. Molina, A. Montecinos, and S. Hormazabal for their help during the writing of this manuscript. This is a contribution of the BIOSOPE project of the LEFE-CYBER program. This research was funded by the Centre National de la Recherche Scientifique (CNRS), the Institut des Sciences de l'Univers (INSU), the Centre National d'Etudes Spatiales (CNES), the European Space Agency (ESA), the National Aeronautics and Space Administration (NASA), and the Natural Sciences and Engineering Research Council of Canada (NSERC). Financial assistance was provided by the FONDAP-COPAS center (Project No. 150100007). J. Charpentier was supported by a grant 
from the MECESUP UCO002 project. This work was supported by the Chilean National Commission for Scientific and Technological Research through FONDECYT grant 1050743 (L. Farias).

Edited by: S. W. A. Naqvi

\section{References}

Aerssens, E., Tiedje, J., and Averill, B.: Isotope labelling studies on the mechanism of N-N bond formation in denitrification, J. Biol. Chem., 261, 9652-9656, 1986.

Alldredge, A. L. and Cohen, Y.: Can Microscale Chemical Patches Persist in the Sea? Microelectrode Study of Marine Snow, Fecal Pellets, Science, 235, 689-691, 1987.

Armstrong, F. A., Stearns, C. R., and Strickland, D. H.: The measurement of upwelling and subsequent biological processes by means of the Technicon Autoanalyzer and associated equipment, Deep Sea Res., 14, 381-389, 1967.

Averill, B. A.: Dissimilatory Nitrite and Nitric Oxide Reductases, Chem. Rev., 96, 2951-2964, 1996.

Averill, B. A. and Tiedje, J. M.: The chemical mechanism of microbioal denitrification, FEBS Lett., 138, 8-12, 1982.

Bonnet, S., Guieu, C., Bruyant, F., Pril, O., Van Wambeke, F., Raimbault, P., Grob, C., Moutin, T., Gorbunov, M. Y., Zehr, J. P., Masquelier, S. M., Garczarek, L., and Claustre, H.: Nutrients limitation of primary productivity in the Southeast Pacific (BIOSOPE cruise), Biogeosciences Discuss., 4, 2733-2759, 2007 , http://www.biogeosciences-discuss.net/4/2733/2007/.

Carlucci, A. F. and McNally, P. M.: Nitrification by Marine Bacteria in Low Concentrations of Substrate and Oxygen, Limnol. Oceanogr., 14, 736-739, 1969.

Claustre, H. and Maritorena, S.: OCEAN SCIENCE: The Many Shades of Ocean Blue, Science, 302, 1514-1515, 2003.

Castro, M. and Farías, L.: $\mathrm{N}_{2} \mathrm{O}$ cycling at the core of the oxygen minimum zone off northern Chile, Mar. Ecol. Prog. Ser., 280, $1-11,2004$

Codispoti, L. A., Brandes, J. A., Christensen, J. P., Devol, A. H., Naqvi, S. W. A., Paerl, H. W., and Yoshinari, T.: The oceanic fixed nitrogen and nitrous oxide budgets: Moving targets as we enter the anthropocene?, Sci. Mar., 65, 85-105, 2001.

Cohen, Y. and Gordon, L. I.: Nitrous oxide production in the ocean, J. Geophys. Res., 84, 347-353, 1979.

Cornejo, M., Farias, L., and Paulmier, A.: Temporal variability in $\mathrm{N}_{2} \mathrm{O}$ water content and its air-sea exchange in an upwelling area off central Chile (36 degrees S), Mar. Chem., 101, 85-94, 2006.

Csanady, G. T.: Circulation in the coastal ocean. Dordrecht, D. Reidel, pp. 279, 1982.

Csanady, G. T.: Mass Transfer to and from Small Particles in the Sea, Limnol. Oceanogr., 31, 237-248, 1986.

Daneri, G., Dellarossa, V., Quinones, R., Jacob, B., Montero, P., and Ulloa, O.: Primary production and community respiration in the Humboldt Current System off Chile and associated oceanic areas, Mar. Ecol. Prog. Ser., 197, 41-49, 2000.

Daneri, G. and Quiñones, R.: Undersampled Ocean systems : a plea for an international study of biogeochemical cycles in the Southern Pacific Gyre and its boundaries, U.S. JGOFS Newsletter, 11, 9,2001
Dore, J. E., Popp, B. N., Karl, D. M., and Sansone, F. J.: A large source of atmospheric nitrous oxide from subtropical North $\mathrm{Pa}-$ cific surface waters, Nature, 396, 63-66, 1998.

Elkins, J. E., Wofsy, S. C., McElroy, M. B., Kolb, C. E., and Kaplan, W. A.: Aquatic sources and sinks for nitrous oxide., Nature, 275 , 602-606, 1978.

Emery, W. J. and Meincke, J.: Global Water masses: summary and review, Oceanol. Acta, 9, 383-391, 1986.

Goreau, T. J., Kaplan, W. A., Wolfsy, M. B., McElroy, M. B., Valois, F. W., and Watson, S. W.: Production of $\mathrm{NO}_{2}^{-}$and $\mathrm{N}_{2} \mathrm{O}$ by nitrifiying bacteria at reduced concentrations of oxygen, Appl. Environ. Microbiol., 40, 526-532, 1980.

Gorsky, G., Picheral, M., and Stemmann, L.: Use of the Underwater Video Profiler for the Study of Aggregate Dynamics in the North Mediterranean, Est. Coast. Shelf Sci., 50, 121-128, 2000.

Gruber, N. and Sarmiento, J. L.: Global patterns of marine fixation and denitrification, Global Biogeochem. Cycles, 11, 235266, 1997.

Hallam, S. J., Mincer, T. J., Schleper, C., Preston, C. M., Roberts, K., Richardson, P. M., and DeLong, E. F.: Pathways of Carbon Assimilation and Ammonia Oxidation Suggested by Environmental Genomic Analyses of Marine Crenarchaeota, PLoS Biology, 4, e95, 2006.

Hendriks, J., Oubrie, A., Castresana, J., Urbani, A., Gemeinhardt, S., and Saraste, M.: Nitric oxide reductases in bacteria, Biochim. Biophys. Acta, 1459, 266-273, 2000.

Kartal, B., Kuypers, M. M. M., Lavik, G., Schalk, J., Op den Camp, H. J. M., Jetten, M. S. M., and Strous, M.: Anammox bacteria disguised as denitrifiers: nitrate reduction to dinitrogen gas via nitrite and ammonium, Environ. Microbiol., 9, 635-642, 2007.

Kim, K. R. and Craig, H.: Two-isotope characterization of $\mathrm{N}_{2} \mathrm{O}$ in the Pacific Ocean and constraints on its origin in deep water, Nature, 347, 58-61, 1990.

Kiørboe, T., Ploug, H., and Thygesen, U.: Fluid motion and solute distribution around sinking aggregates. I. Small-scale fluxes and heterogeneity of nutrients in the pelagic environment, Mar. Ecol. Prog. Ser., 211, 1-13, 2001.

Knowles, R.: Denitrification, Microbiol. Rev., 46, 43-70, 1982.

Konneke, M., Bernhard, A. E., de la Torre, J. R., Walker, C. B., Waterbury, J. B., and Stahl, D. A.: Isolation of an autotrophic ammonia-oxidizing marine archaeon, Nature, 437, 543-546, 2005.

Law, C. S. and Ling, R. D.: Nitrous oxide flux and response to increased iron availability in the Antarctic Circumpolar Current, Deep-Sea Res. II, 48, 2509-2527, 2001.

Liao, T., Camp, C., and Yung, Y.: The seasonal cycle of $\mathrm{N}_{2} \mathrm{O}$, Geophys. Res. Lett., 31, L17108, doi:10.1029/2004GL020345, 2004.

Manne, A. S. and Richels, R. G.: An alternative approach to establishing trade-offs among greenhouse gases, Nature, 410, 675677, 2001.

Morales, C., Blanco, J., Braun, M., Reyes, H., and Silva, N.: Chlorophyll-a distribution and associated oceanographic conditions in the upwelling region off northern Chile during the winter and spring 1993, Deep Sea Res. I, 43, 267-289, 1996.

Murray, C. N. and Riley, J. P.: The solubility of gases in distilled water and sea water-II. Oxygen, Deep Sea Res., 16, 311-320, 1969.

Naqvi, S. W. A. and Noronha, R. J.: Nitrous oxide in the Arabian Sea, Deep-Sea Res. A, 38, 871-890, 1991. 
Naqvi, S. W. A., Yoshinari, T., Jayakumar, D. A., Altabet, M. A., Narvekar, P. V., Devol, A. H., Brandes, J. A., and Codispoti, L. A.: Budgetary and biogeochemical implications of $\mathrm{N}_{2} \mathrm{O}$ isotope signatures in the Arabian Sea, Nature, 394, 462-464, 1998.

Nevison, C., Butler, J. H., and Elkins, J. W.: Global distribution of $\mathrm{N}_{2} \mathrm{O}$ and the $\Delta \mathrm{N}_{2} \mathrm{O}$-AOU yield in the subsurface ocean, Global Biogeochem. Cycles, 17, 30-1-30-18, 2003.

Nevison, C. D., Weiss, R. F., and Erickson, D. J., III.: Global oceanic emissions of nitrous oxide, J. Geophys. Res., 100, 809820,1995

Ostrom, N. E., Russ, M. E., Popp, B., Rust, T. M., and Karl, D. M.: Mechanisms of nitrous oxide production in the subtropical North Pacific based on determinations of the isotopic abundances of nitrous oxide and di-oxygen, Chemosphere - Global Change Sci., 2, 281-290, 2000.

Oudot, C., Andrie, C., and Montel, Y.: Nitrous oxide production in the tropical Atlantic Ocean, Deep-Sea Res., 37, 183-202, 1990.

Oudot, C., Jean-Baptiste, P., Fourre, E., Mormiche, C., Guevel, M., Ternon, J.-F., and Le Corre, P.: Transatlantic equatorial distribution of nitrous oxide and methane, Deep-Sea Res. I, 49, 11751193, 2002.

Ploug, H.: Small-Scale Oxygen Fluxes and Remineralization in Sinking Aggregates, Limnol. Oceanogr., 46, 1624-1631, 2001.

Ploug, H. and Kühl, M., Buchholz-Cleven, B. and Jørgensen, B.: Anoxic aggregates - an ephemeral phenomenon in the pelagic environment?, Aquat. Microb. Ecol., 13, 285-294, 1997.

Popp, B., Westley, M. , Toyoda, S., Miwa, T., Dore, J., Yoshida, N., Rust, T., Sansone, F., Russ, M., Ostrom, N. and Ostrom, P.: Nitrogen and oxygen isotopomeric constraints on the origins and sea-to-air flux of $\mathrm{N}_{2} \mathrm{O}$ in the oligotrophic subtropical North Pacific gyre, Global Biogeochem. Cycles, 16, 1064-1073, 2002.

Poth, M. and Focht, D.: ${ }^{15} \mathrm{~N}$ Kinetic analysis of $\mathrm{N}_{2} \mathrm{O}$ production by Nitrosomonas europaea: an examination of nitrifier denitrification, Appl. Envir. Microbiol., 49, 1134-1141, 1985.

Raimbault, P., Slawyk, G., Coste, B., and Fry, J.: Feasibility of using an automated colorimetric procedure for the determination of seawater nitrate in the 0 to $100 \mathrm{nM}$ range: Examples from field and culture, Mar. Biol., 104, 347-351, 1990.

Ritchie, G. A. and Nicholas, D. J.: Identification of the sources of nitrous oxide produced by oxidative and reductive processes in Nitrosomonas europaea, Biochem. J., 126, 1181-1191, 1972.

Schmidt, H. L., Werner, R. A., Yoshida, N., and Well, R.: Is the isotopic composition of nitrous oxide an indicator for its origin from nitrification or denitrification? A theoretical approach from referred data and microbiological and enzyme kinetic aspects, Rapid Commun. Mass Spectrom., 18, 2036-2040, 2004.

Shaw, L. J., Nicol, G. W., Smith, Z., Fear, J., Prosser, J. I., and Baggs, E. M.: Nitrosospira spp. can produce nitrous oxide via a nitrifier denitrification pathway, Environ. Microbiol., 8, 214222, 2006

Silva, N. and Neshyba, S.: On the southernmost extension of the Peru-Chile undercurrent, Deep Sea Res., 26, 1387-1393, 1979.

Stein, L. Y. and Arp, D. J.: Loss of Ammonia Monooxygenase Activity in Nitrosomonas europaea upon Exposure to Nitrite, Appl. Environ. Microbiol., 64, 4098-4102, 1998.

Stemmann, L., Picheral, M., and Gorsky, G.: Diel variation in the vertical distribution of particulate matter $(>0.15 \mathrm{~mm})$ in the NW Mediterranean Sea investigated with the Underwater Video Profiler, Deep-Sea Res. I, 47, 505-531, 2000.
Strub, T., Mesias, J. M., Monecino, V., Rutlland, J., and Salinas, S.: Coastal Ocean Circulation off Western South America, in: The Sea, edited by: Robinson, A. R. and Brinks, K. H., New York, John Wiley and Sons, 11, 273-213 1995.

Sutka, R., Ostrom, N., Ostrom, P., Gandhi, H., and Breznak, J.: Nitrogen isotopomer site preference of $\mathrm{N}_{2} \mathrm{O}$ produced by Nitrosomonas europaea and Methylococcus capsulatus Bath, Rapid Commun. Mass Spectrom., 17, 738-745, 2003.

Sutka, R., Ostrom, N., Ostrom, P., Gandhi, H., and Breznak, J.: Erratum: Nitrogen isotopomer site preference of $\mathrm{N}_{2} \mathrm{O}$ produced by Nitrosomonas europaea and Methylococcus capsulatus Bath, Rapid Commun. Mass Spectrom., 18, 1411-1412, 2004.

Sutka, R. L., Ostrom, N. E., Ostrom, P. H., Breznak, J. A., Gandhi, H., Pitt, A. J., and Li, F.: Distinguishing Nitrous Oxide Production from Nitrification and Denitrification on the Basis of Isotopomer Abundances, Appl. Environ. Microbiol., 72, 638-644, 2006.

Toyoda, S., Mutobe, H., Yamagishi, H., Yoshida, N., and Tanji, Y.: Fractionation of $\mathrm{N}_{2} \mathrm{O}$ isotopomers during production by denitrifier, Soil Biol. Biochem., 37, 1535-1545, 2005.

Toyoda, S. and Yoshida, N.: Determination of Nitrogen Isotopomers of Nitrous Oxide on a Modified Isotope Ratio Mass Spectrometer, Anal. Chem., 71, 4711-4718, 1999.

Toyoda, S., Yoshida, N., Miwa, T., Matsui, Y., Yamagishi, H., Tsunogai, U., Nojiri, Y., and Tsurushima, N.: Production mechanism and global budget of $\mathrm{N}_{2} \mathrm{O}$ inferred from its isotopomers in the western North Pacific, Geophys. Res. Lett., 29, 25-28, 2002.

Tréguer, P. and LeCorre, P.: Manuel d'analyses des sels nutritifs dans l'eau de mer (Utilisation de l'Autoanalyser II). Brest, Laboratoire. de Chimie Marine, Université de Bretagne Occidentale, pp. 110 pp, 1975.

Treusch, A. H., Leininger, S., Kletzin, A., Schuster, S. C., Klenk, H.-P., and Schleper, C.: Novel genes for nitrite reductase and Amo-related proteins indicate a role of uncultivated mesophilic crenarchaeota in nitrogen cycling, Environ. Microbiol., 7, 19851995, 2005.

Ward, B.: Nitrification and the marine nitrogen cycle, in: Microbial Ecology of the Oceans, edited by: Kirchman, D., New York, Wiley - Liss, 427-453, 2000.

Wasser, I. M., de Vries, S., Moënne-Loccoz, P., Schröder, I., and Karlin, K.: Nitric Oxide in Biological Denitrification: $\mathrm{Fe} / \mathrm{Cu}$ Metalloenzyme and Metal Complex $\mathrm{NO}_{\mathrm{x}}$ Redox Chemistry, Chem. Rev., 102, 1201-1234, 2002.

Weeg-Aerssens, J. M., Tiedje, J. M., and Averill, B. A.: Evidence from isotope labeling studies for a sequential mechanism for dissimilatory nitrite reduction, J. Am. Chem. Soc., 110, 6851-6856, 1988.

Westley, M. B., Yamagishi, H., Popp, B. N., and Yoshida, N.: Nitrous oxide cycling in the Black Sea inferred from stable isotope and isotopomer distributions, Deep Sea Res. II, 53, 1802-1816, 2006.

Wrage, N., Velthof, G. L., van Beusichem, M. L., and Oenema, O.: Role of nitrifier denitrification in the production of nitrous oxide, Soil Biol. Biochem., 33, 1723-1732, 2001.

Yamagishi, H., Miwa, T., Toyoda, S., Tsunogai, U., and Yoshida, N.: A method for the Measurement of Dissolved Nitrous Oxide Isotopomers in Natural Waters. 1st International Symposium on Isotopomers, Yokohama, Japan, 2001.

Yamagishi, H., Yoshida, N., Toyoda, S., Popp, B., Westley, M., 
and Watanabe, S.: Contributions of denitrification and mixing on the distribution of nitrous oxide in North Pacific, Geophys. Res. Lett., 32, L04603, doi:10.1029/2006JG000227, 2005.

Yoshida, $\mathrm{N}$.: ${ }^{15} \mathrm{~N}$-depleted $\mathrm{N}_{2} \mathrm{O}$ as a product of nitrification, Nature, 335, 528-529, 1988.

Yoshida, N., Morimoto, H., Hirano, M., Koike, I., Matsuo, S., Wada, E., Saino, T., and Hattori, A.: Nitrification rates and ${ }^{15} \mathrm{~N}$ abundances of $\mathrm{N}_{2} \mathrm{O}$ and $\mathrm{NO}_{3}^{-}$in the western North Pacific, Nature, 342, 895-897, 1989.

Yoshida, N. and Toyoda, S.: Constraining the atmospheric $\mathrm{N}_{2} \mathrm{O}$ budget from intramolecular site preference in $\mathrm{N}_{2} \mathrm{O}$ isotopomers, Nature, 405, 330-334, 2000.
Yoshinari, T.: Nitrous oxide in the sea, Mar. Chem., 4, 189-202, 1976.

Zafiriou, O., Hanley, Q., and Snyder, G.: Nitric oxide and nitrous oxide production and cycling during dissimilatory nitrite reduction by Pseudomonas perfectomarina, J. Biol. Chem., 264 5694-5699, 1989.

Zuñiga, J., Bastida, A., and Requena, A.: Theoretical calculations of vibrational frequencies and rotational constants of the $\mathrm{N}_{2} \mathrm{O}$ isotopomers, J. Mol. Spectrosc., 217, 43-58, 2003. 